


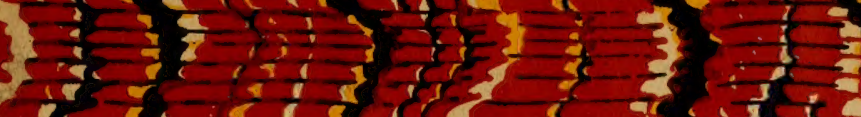
(2)

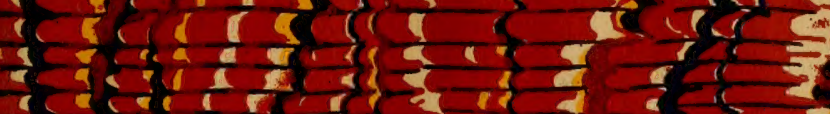

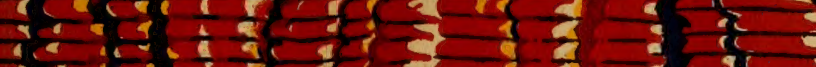

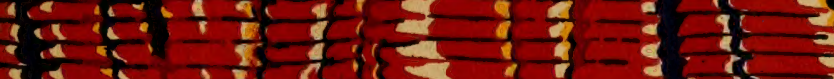

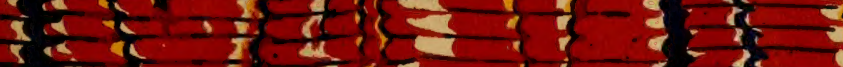

$12-6.25$

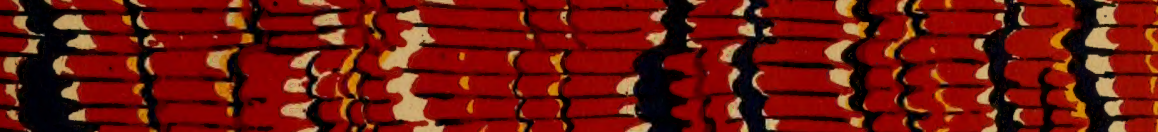

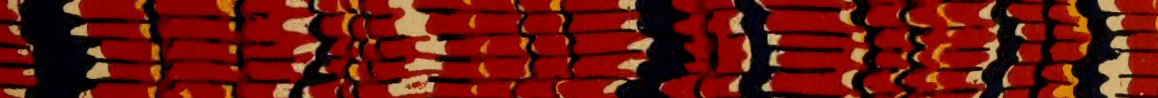

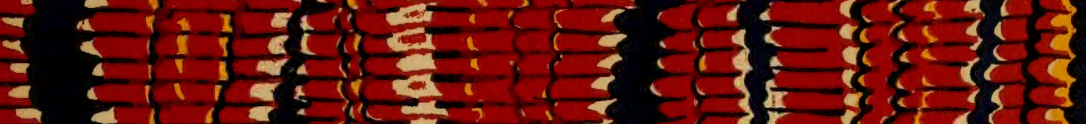

a है।

है

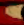

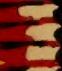

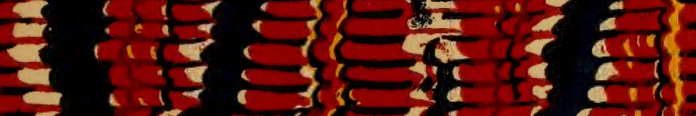

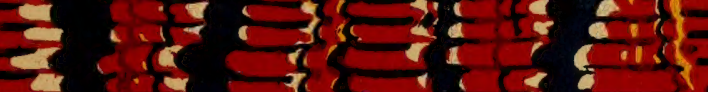

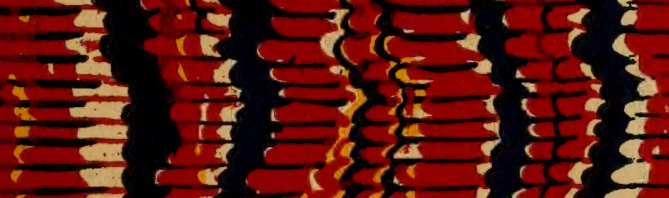
$-10-1: 5$

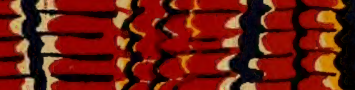
If $\left\{\begin{array}{c}5 \\ 2\end{array}\right.$

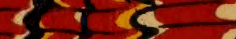

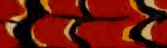
$5<x<5 ?$ 3 - $\left.3: \frac{1}{4}\right\}$

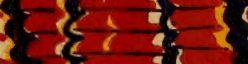

3

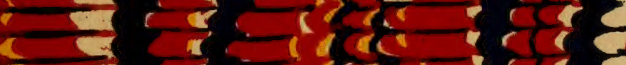

a 30 ? 3

a 30

a

$=2,3=1$

$\Rightarrow\{\{-3=2\}$

$\frac{7}{2}$

1

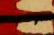

s

$34-2<$

ic 1 is

$r^{2} i \frac{1}{4}$

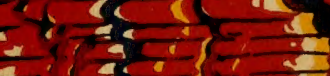

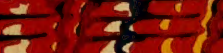
$4: 45+3$ $\frac{7}{4}: \frac{1}{4}$

$c$ a 1 i

(1) 45

IR

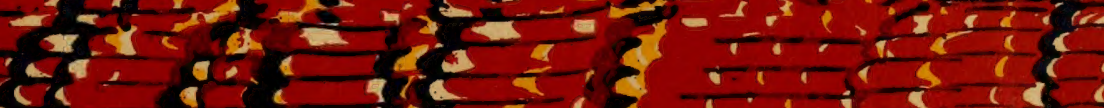

8

1. 35 तंi ce $=2 \div$ $\therefore i^{5} i d s$

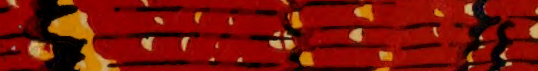

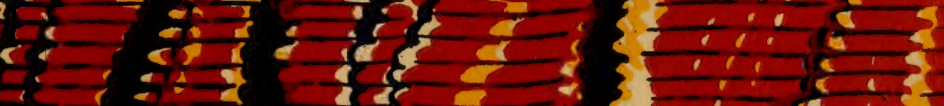

$\frac{1}{1}$ ,

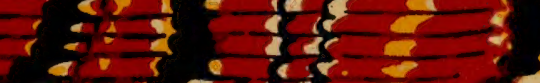
कर is $1<1,1<$

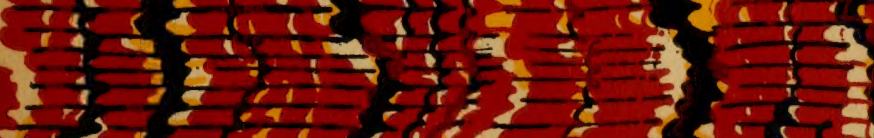

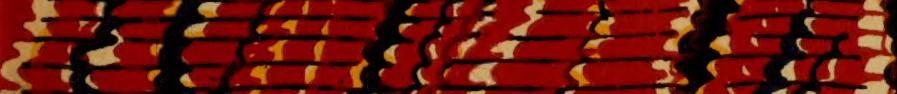

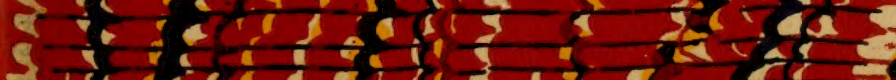



From the Annals and Magazine of Natural Histori,

Ser. 7, Vol. viii., November 1901.

On some Entomostraca collected in the Arctic Seas in 1898 by William S. Bruce, F.R.S.G.S. By Thomas Scotт, F.L.S., and ANDrew ScotT.

[Plates III.-VI.]

THE Entomostraca recorded here were collected by William S. Bruce, in June and July 1898, while cruising in the Arctic Seas with Mr. Andrew Coats in his steam yacht the 'Blencathra.' These micro-crustracea consisted chiefly of Copepoda; some Ostracoda were obtained, but they comprised only a few moderately common species, while the Cladocera were represented by one or two examples of the ephippia of Daphnia sp.

The Copepoda number 59 species in all, and they belong to the following nine families, viz.:- to the Calanidæ, 4 species; the Centropagidæ, 3 species; the Pseudocyclopidæ, 1 species; the Pontellidæ, 2 species; the Cyclopidæ, 4 species; the Harpacticidæ, 40 species; the Lichomolgidæ, 1 species; and the Asterocheridæ, 4 species. It will be observed that the largest number of species (40) belong to the Harpacticidæ ; most of them, however, are represented by only a few specimens. On the other hand, the species in the collection represented by the largest number of specimens Ann. \& Mag. N. Hist. Ser. 7. Vol. viii. 
was Calanus finmarchicus-some of the tow-net gatherings collected by Mr. Bruce consisted almost entirely of this species.

Most of the Copepoda recorded here, with the exception of Calanus finmarchicus and a few other pelagic forms, were collected in the neighbourhood of Kolguev, and between that island and Kostyn Point, near the south end of Novaya Zemlia ; several species were also dredged in the vicinity of Bear and Hope Islands off the south-east of Spitzbergen, as well as in moderately deep water (100 to 110 fathoms) to the eastward of Hope Island.

The Copepoda from the vicinity of Kolguev and Kostyn Point were collected in June, while those obtained in the neighbourhood of Bear and Hope Islands were collected in July.

The following are the species of Copepoda collected by Mr. Bruce in 1898, so far as they have been identified by us*.

\section{Fam. Calanidæ.}

\section{Calanus finmarchicus (Gunner).}

This was by far the most common of the Copepods collected by Mr. Bruce; but though it was present in most of the tow-net gatherings, it was not equally plentiful-in one it might occur in large numbers, while in another, collected perhaps the next day or even the same day, only a few specimens would be observed. It would thus appear that in those parts of the Barents Sea visited by the 'Blencathra' the distribution of this species was not uniform, but that it rather occurred in shoals. It should be noted in passing that most of the tow-net gatherings were collected at or near the surface, so that our remarks apply only to the surfacedistribution of the species.

\section{Calanus hyperboreus, Kröyer.}

This species was not observed in any of the gatherings collected in June in the neighbourhood of Kolguev, but it occurred in several of those collected in July. It was, for example, obtained in gatherings from the vicinity of Hope Island, collected on the 5th and 6 th ; in one collected southeast of South Cape, Spitzbergen (lat. $76^{\circ} 29^{\prime}$ N., long.

* The Rev. T. R. R. Stebbing, M.A., F.R.S., has already, in Ann. \& Mag. Nat. Hist. (7) vol. v. pp. 1-16 (Jan. 1900), published a report on the higher forms of Crustacea collected by Mr. Bruce during his cruise with Mr. Coats on board the s.y. 'Blencathra.' 
$19^{\circ} 08^{\prime}$ E.), on the $22 \mathrm{nd}$; and in one from Kval Sound, collected on the 24 th; but in none of the gatherings was the species very common.

\section{Pseudocalanus elongatus, Boeck.}

This species occurred in one or two gatherings collected between Kolguev and the neighbouring shores of Novaya Zemlya in June; and in July in the vicinity of Hope Island, in various parts of the Barents Sea, and in Kval Sound, but nowhere very common.

\section{Pseudocalanus pygmaeus, G. O. Sars.}

1900. Pseudocalanus pygmceus, G. O. Sars, The Norweyian North Polar Expedition, 189:3-96,-Scientific results, edited by Fridtjof Nansen, No. v. Crustacea, by G. O. Sars, p. 73, pl. xxi.

Several specimens of this moderately distinct species were obtained in a gathering collected near the shore on the east side of Kolguev Island on June 12th. A number of other species, such as Oithona helgolandica, Jonesiella spinulosa, Platychelipus littoralis, and Idya furcata, were also observed. Prof. G. O. Sars states that Pseudocalanus pygmeus "occurred in considerable numbers in samples taken north of the New Siberian Islands in October 1893," and adds that no male specimen was found. With regard to the apparent absence of male specimens noted by Professor Sars, it may be of interest to remark that we also failed to obtain a single male amongst the specimens collected by Mr. Bruce. 'This absence of male specimens made us at first somewhat doubtful concerning the species to which the specimens observed by us should be ascribed, but after careful examination of them we are satisfied that they are identical with the Pseudocalanus pygmaus of G. O. Sars.

\section{Fam. Centropagidæ.}

Centropages hamatus (Lilljeborg).

The only gathering in which this species was observed was one collected in Kval Sound on the 24th of July-it was a tow-net gathering trom near the surface of the water. Only one or two specimens of the Centropages were observed.

Temora longicornis (Müller).

This species, which is sometimes exceedingly common in the British seas, occurred in the same gathering with the 
Centropages just recorded. This was the only gathering in which it was observed and a few specimens only were obtained.

\section{Metridia longa (Lubbock).}

Metridia longa appears to be a true Arctic Copepod, and is sometimes moderately abundant in samples of the Copepod fauna of the far north; yet, with the exception of the one from Kval Sound in which the Centropages and Temora were obtained, the species was observed in none of those collected by Mr. Bruce in June and July 1898 and examined by us, and even in the gathering from Kval Sound only a few specimens were observed.

Fam. Pseudocyclopidæ.

Pseudocyclops obtusatus, Brady \& Robertson.

1873. Pseudocyclops obtusatus, Brady \& Robertson, Ann. \& Mag. Nat. Hist. (4) vol, xii. p. 12, pl. viii. figs. 4-7.

This species was dredged on the west side of Bear Island on July 3rd, in moderately shallow water, and was apparently very rare.

\section{Fam. Pontellidæ.}

\section{Anomalocera Patersonii, R. Templeton.}

1837. Anomalocera Patersonii, R. Templ. Trans. Ent. Soc. Lond. vol. ii. p. 34, pl. v. figs. 1-3.

Specimens of this fine species were obtained in a tow-net gathering collected at the entrance to Kval Fjord, and in another from Kval Sound; both gatherings were collected on July 24th.

\section{Acartia longiremis (Lilljeborg).}

Taken by surface tow-net off Kostyn Point, Novaya Zemlya, on June 17th, off Hope Island on July 7th, and in Kval Sound on July 24th; not very common. Acartia longiremis is recorded by Sars from north of the New Siberian Islands*.

* Norwegian North Polar Exped. 1893-96, Crustacea, p. 106 (1900). 


\section{Fam. Cyclopidæ.}

* Oithona helgolandica, Claus.

The species we record under this name appears to be identical with that from the British seas, which, according to Sars, has been wrongly described as $O$. spinifrons of Boeck, but which is equal to the O.pygmeea of the same author. He shows further that Boeck's O. pygmea is identical with $O$. helgolandica, Claus; and as Claus's name is the older it takes precedence of the other. O. helyolandica was observed in several gatherings; it was obtained in two from the vicinity of Kolguev collected in June, and in others collected between Bear and Hope Islands, and in $\mathrm{Kval}$ Sound in July.

\section{Cyclopina gracilis, Claus.}

This small but distinct species was obtained in some dredged material from two places, viz. from moderately shallow water near Kolguev Island in June, and in July in material from 100 to 110 fathoms to the east of Hope Island. Only one or two specimens were observed. This species has also been taken by Mr. Bruce near Cape Flora, FranzJosef Land $\dagger$.

\section{Thorellia brunnea, Boeck.}

Thorellia was obtained sparingly amongst some material dredged in 20 fathoms between the Island of Kolguev and the south-west end of Novaya Zemlya on the 16th of June. It has also been recorded from near Elmwood, Franz-Josef Land $\neq$. The species is also frequent in the British seas.

\section{Cyclops (?) bisetosus, Rehberg.}

The small Cyclops which we ascribe to C.bisetosus agrees with that species in having comparatively short 17 -jointed antennules, and in the end joints of the fitth pair of thoracic feet being narrow-cylindrical, and having the short terminal bristle setiform rather than minute and tooth-like as in C. vernalis. The receptaculum seminis also closely resembles that of $C$. bisetosus. But, on the other hand, our specimens have the lateral extremities of the fifth segment

* Sars, op cit. p. 119, removes Oithona from the fam. Cyclopidæ to a new family - the Oithonidæ.

$\dagger$ T. Scott, "On the Crustacea of Franz-Josef Land," Journ. Linn. Soc. (Zool.) vol. xxvii. no. 174 (July 1899), p. 93.

$\ddagger$ T. Scott, op. cit. p. 93. 
of the cephalothorax narrowly produced and sinuate, so as to be somewhat similar in this respect to $C$. vernalis, and but for this we should have had no hesitation in ascribing our specimens to Rehberg's species. These specimens were collected by Mr. Bruce in a freshwater pond near Kostyn Point, Novaya Zemlya, on June 18th, 1898.

\section{Fam. Harpacticidæ.}

\section{Ectinosoma Sarsi, Boeck.}

This species was dredged on the east side of Kolguev, and also from 27 fathoms in the vicinity of Hope Island; only a few specimens were observed.

\section{Ectinosoma curticorne, Boeck.}

This also occurred very sparingly in the sample from the east side of Kolguev, which was the only gathering where Ectinosoma curticorne was observed.

\section{Ectinosoma melaniceps, Boeck.}

One or two specimens of Ectinosoma melaniceps were obtained in some material dredged in 100 fathoms to the east of Hope Island on July 13th.

\section{Ectinosoma atlanticum (Brady \& Robertson).}

This small species was of general occurrence in the townet gatherings collected by Mr. Bruce in the summer of 1898 , and appeared to be more or less generally distributed over the Barents Sea from Kolguev to Spitzbergen; in none of the gatherings, however, was it very plentiful.

\section{Zosima typica, Boeck.}

This species occurred very sparingly in some material dredged in 100 fathoms to the east of Hope Island on July 13 th.

Robertsonia tenuis (Brady \& Robertson).

This was obtained in the same gathering with Zosima typica, but appeared to be rare. Robertsonia tenuis is one of the species recorded by T. Scott from Franz-Josef Land, and it also appears to be widely distributed in the British seas. 


\section{Amymone sphorica, Claus.}

One or two specimens of an Amymone that appear to belong to this species were dredged in 20 fathoms between Kolguev and the neighbouring shores of Novaya Zemlya on the 16th of June.

\section{Ameira longipes, Boeck.}

This species occurred very sparingly in some material dredged in 20 fathoms off Kolguev on June 11th, and in 27 fathoms in the vicinity of Hope Island on July 6th.

\section{Jonesiella spinulosa (Brady \& Robertson).}

A few specimens of Jonesiella spinulosa were found in a shore-gathering from the east side of Kolguev Island, collected on June $12 \mathrm{th}$, and in some material dredged in 60 fathoms in lat. $76^{\circ} 17^{\prime}$ N., long. $21^{\circ} 36^{\prime}$ E., on July 20 th.

\section{Jonesiella Brucei *, T. \& A. Scott (sp. n.). (Pl. III.)}

Description of the Species. - The length of the female represented by the drawing (fig. 1) is $98 \mathrm{~mm}$. (nearly $\frac{1}{2} 5$ of an inch). The body is moderately stout and terminates anteriorly in a prominent rostrum ; the abdomen is comparatively short, while the caudal furca are slender and about as long as the entire length of the last three abdominal segments.

The antennules are short and six-jointed; the first two and the last joints are of nearly equal length and longer than any of the other three, the penultimate joint is very small, while the third and fourth are together about equal in length to the second joint. The formula shows approximately the proportional lengths of the different joints:-

$\begin{array}{llllllll}\text { Number of the joints } & \ldots \ldots & 1 & 2 & 3 & 4 & 5 & 6 \\ \text { Proportional lengths } & \ldots . . & \frac{1}{28} \cdot 23.12 & .8 & .6 & .23\end{array}$.

The antennules, as shown by the drawing (fig. 2), are provided with numerous moderately long setæ. 'The antennæ (fig. 3) are somewhat like those of Jonesiella hycence, I. C. 'Thompson, in their general structure, the secondary branches being also three-jointed, as in that species.

The mandibles (fig. 4) are moderately stout and furnished with a well-developed two-branched palp, but the branches appear to be uniarticulate. The maxillæ (fig. 5) are somcwhat like those of Jonesiella fusiformis, G. S. Brady; the

* Named after Mr. W. S. Bruce, to whom we are indebted for the privilege of describing the species. 
masticatory lobe is stout and armed with several setiferous spines, and the palp has a somewhat complex lobate structure; the basal joint of the palp, which is articulated near the middle of the masticatory lobe and extends forward alongside of it, is moderately stout; the secondary joint is scarcely so broad as the terminal part of the basal joint, and is provided with two small supplementary branches.

The maxillipeds resemble those of Jonesiella spinulosa (Brady and Robertson) ; figure 6 represents one of the second maxillipeds.

The swimming-feet are also somewhat like those of the species just referred to, except that the first pair do not appear to be so strongly setiferous. The two-jointed inner branches of the first pair (fig. 7) are about as long as the three-jointed outer branches. In the next three pairs, which are all somewhat similar in structure, the inner as well as the outer branches are three-jointed (fig. 8). In the fifth pair the secondary joints appear to be more or less coalescent with the basal joints as shown in the drawing (fig. 9), and thus assume a bilobed appearance; the inner lobe bears four elongated setæ, two of which spring from the distal half of the interior margin and two from the apex, while the outer lobe carries one long and one short apical seta, as well as a moderately stout seta on the exterior margin.

No males of this species have been observed.

Habitat. Deep water (100 to 110 fathoms) to the east of Hope Island, very rare. Only one or two specimens of this distinct species have been observed by us.

\section{Delavalia arctica, T. Scott.}

1899. Delavalia arctica, T. Scott, "Crust. from Franz-Josef Land," Journ. Linn. Soc., Zool. vol. xxvii. p. 98, pl. v. fig. 14, pl. vi. figs. 7-11.

One or two specimens of this recently described Delavalia were obtained in a shore-gathering from the east side of Kolguev Island, collected on June 12th, 1898.

\section{Canthocamptus staphylinus (Jurine).}

This widely distributed species was moderately common in a gathering from a large inland pond near Kostyn Point, Novaya Zemlya, collected on June 18th.

\section{Canthocamptus palustris, G. S. Brady.}

This species, which was very rare in the gathering examined, was collected in a pond about one mile inland, on an 
extensive sandy shore on the east side of Kolguev Island, on June 12th. The water of the pond appeared to be brackish.

\section{Mesochra Lilljeborgi, Boeck.}

A few specimens of Mesochra Lilljeborgi occurred in the same gathering with Delavalia arctica, from the east side of Kolguev Island.

\section{Laophonte horrida, Norman.}

This curious species was observed in gatherings from the following localities :-West side of Bear Island, collected on July 3rd; five miles west of Hope Island in 17 fathoms, collected on July 5th or 6th ; and near the same locality as the last, but in 27 fathoms, collected July 6th. The species was rare in all the three samples examined.

\section{Loaphonte curticauda, Boeck.}

This species was very rare; it occurred in a gathering from 20 fathoms off the north end of Kolguev, collected June 11th ; in one from 12 fathoms off the south-west end of Novaya Zemlya, collected June 17 th ; and in a gathering from 60 fathoms, collected on July 20 th in lat. $76^{\circ} 17^{\prime} \mathrm{N}$., long. $21^{\circ} 36^{\prime} \mathrm{E}$.

\section{Laophonte longicaudata, Boeck.}

L. Tongicaudata occurred in a gathering from 100 fathoms collected on July 13 th in lat. $76^{\circ} 24^{\prime} \mathrm{N}$., long. $33^{\circ} 43^{\prime} \mathrm{E}$.; the species was apparently very rare.

\section{Laophonte perplexa, T. Scott.}

1899. Laophonte perplexa, T. Scott, op. cit. p. 103, pl. vii. figs. 1-7.

A few specimens of this species were dredged in 27 fathoms west of Hope Island on July 6th. The species was described in 1899 from specimens collected by Mr. Bruce off Cape Flora, Franz-Josef Land, and is one that requires careful examination.

\section{Laophonte serrata (Claus).}

This fine species was obtained in some dredged material from the vicinity of Bear Island collected on July 3rd, but was apparently very rare. 


\section{Cletodes longicaudata, Brady \& Robertson.}

One or two specimens apparently belonging to Cletodes longicaudata occurred in a sample of bottom-material from 100 fathoms collected on July 13 th in lat. $76^{\circ} 24^{\prime} \mathrm{N}$., long. $33^{\circ} 43^{\prime} \mathrm{E}$.

\section{Cletodes tenuipes, T. Scott.}

1897. Cletodes tenuipes, T. Scott, Fifteenth Ann. Rept. Fishery Board for Scotland, pt. iii. p. 170, pl. i. figs. 19-27.

The sample in which Cletodes tenuipes was obtained was collected in 60 fathoms in lat. $76^{\circ} 17^{\prime} \mathrm{N}$., long. $21^{\circ} 36^{\prime} \mathrm{E}$., on July 20th, and was the only gathering in which the species was observed.

\section{Cletodes linearis (Claus).}

This fine species was observed, though very sparingly, in a sample of bottom-material collected in 20 fathoms off Kostyn Point, Novaya Zemlya, and in another from 100 fathoms collected on July 13 th in lat. $76^{\circ} 24^{\prime} \mathrm{N}$., long. $33^{\circ} 43^{\prime} \mathrm{E}$.

\section{Cletodes similis, T. Scott.}

1895. Cletodes similis, T. Scott, Thirteenth Ann. Rept. Fishery Board for Scotland, pt. iii. p. 168, pl. iii. figs. 22-26, pl. iv. figs. 1-3.

One or two specimens of this species occurred in a gathering from 60 fathoms collected on July 20 th in lat. $76^{\circ} 17^{\prime} \mathrm{N}$., long. $21^{\circ} 36^{\prime} \mathrm{E}$.

Cletodes Brucei, T. \& A. Scott (sp. n.). (Hl. V. figs. 9-11.)

A single specimen of a slender Cletodes occurred in a sample of bottom-material collected on the 13 th of July, at the depth of 100 fathoms east of Hope Island, in lat. $76^{\circ} 24^{\prime} \mathrm{N}$., long. $33^{\circ} 43^{\prime} \mathrm{E}$.; and as it belongs to an apparently undescribed species we submit the following description, which, owing to the want of specimens for dissection, is somewhat incomplete.

The specimen, which appeared to be a female, measured about $6 \mathrm{~mm}$. ( $\frac{1}{40}$ of an inch) in length. The animal, seen from above, is of a narrow cylindrical form, and each segment is furnished with one or two pairs of minute lateral bristles (fig. 9) ; the rostrum is very short, and the forehead somewhat truncate; the caudal furca are moderately elongated, slender, and wide apart, and about equal in length to the last abdominal segment. 'T'he antennules are very short, but we were unable to make out the structure of these and of the mouth-appendages. 
The thoracic feet are very slender. The outer branches are moderately elongated and three-jointed, while the inner branches, which in the second, third, and fourth pairs are considerably shorter than the outer ones, are two-jointed; figure 10 on Plate V. represents the fourth pair. The preparation of the first pair was too imperfect for drawing. In the fifth pair (fig. 11) the basal joint is scarcely developed, but the secondary joint (or branch) is extremely elongated and slender, and bears a few apical setæ, and one on the distal half of the outer margin; a slender process forming the base of a small seta extends from the outer aspect of the basal joint.

The peculiar form of this Copepod, together with the slender thoracic feet, and especially the extremely long and slender secondary branches of the fifth pair, distinguish it from any other species of Cletodes known to us.

Cletodes abyssicola, T. \& A. Scott (sp. n.). (Pl. V. figs. 1-8.)

Description of the Female.-Length from the forehead to the end of the caudal furca about $9 \mathrm{~mm}$. ( $\frac{1}{23}$ of an inch). Viewed from above the body is nearly cylindrical, and the posterior margins of the various segments are fringed with minute bristles; the cephalic segment is armed with a strong and backward-curved median dorsal spine, and a small spine also arises from the median dorsal aspect of the last abdominal segment, as shown in the drawing (fig. 1 ; figs. $a$ and $b$ show the anterior and posterior dorsal spine as seen in profile). The caudal furca are long and slender, being nearly equal to half the entire length of the body.

The antennules are moderately elongated and seven-jointed; the second and third joints are subequal, and are together about as long as the entire length of the remaining four joints, which are also subequal. The proportional lengths of the joints are shown approxinately by the formula :-

$\begin{array}{lllllllll}\text { Number of the joints..... } & 1 & 2 & 3 & 4 & 5 & 6 & 7 \\ \text { Lengths of the joints..... } & 12 & 21 & 28 & 11 & 13 & 11 & 11\end{array}$.

The antennules are sparingly setiferous, and the third joint bears a moderately long asthetask (fig. 2 ).

The secondary branches of the antennæ are almost obsolete, being each reduced to a single seta, which springs from the end of the second joint (fig. 3).

The mandibles are moderately stout and provided with a comparatively broad masticatory part; the palp is small and composed of two joints, the second of which is very minute, both joints bear a ferv terminal setæ (fig. 4). 
The posterior foot-jaws are small but moderately robust; a stout seta springs from the inner distal angle of the first joint, while the end joint bears a moderately stout terminal claw (fig. 5).

In the first pair of thoracic feet (fig. 6) the second and third joints of the outer branches are together about equal in length to the first joint; the inner branches are uniarticulate and more or less rudimentary. The second, third, and fourth pairs are somewhat similar to each other in structure; the outer branches, which are all three-jointed, are long and slender, the first and third joints are elongated and subequal, but the middle joint is short; the inner branches are nearly obsolete, being each composed of a single minute joint bearing two small terminal setæ, as shown by figure 7 , which represents the fourth pair. In the fifth pair the secondary branches are elongated and very slender, and provided with three terminal setæ of unequal length, the innermost being the smallest, a small seta also springs from near the middle of the outer margin, as shown in the drawing; the basal joint, which forms a narrow border along the edge of the thoracic segment, bears a small seta near its inner extremity, while it terminates exteriorly in forming the base of a long slender seta (tig. 8 ).

Habitat.-Lat. $76^{\circ} 17^{\prime} \mathrm{N}$., long. $21^{\circ} 36^{\prime}$ E., 60 fathoms; rare. Only a single specimen of this very distinct form was observed. It combines in some measure the general characters of Cletodes monensis, I. C. Thompson, and C. longicaudata, Brady \& Robertson, having the dorsal hooks of the one and the long caudal furca of the other.

Nannopus palustris, Brady.

One or two specimens of this species occurred in a gathering from the east side of Kolguev Island collected on June 12th; this is a littoral as well as a brackish-water species.

\section{Platychelipus littoralis, Brady.}

This species, which bears a general resemblance to $N$ annopus and is frequently found in the British seas associated with that form, was obtained sparingly in the same gathering with it from the east side of Kolguev Island.

\section{Dactylopus tenuiremis, Brady \& Robertson.}

The gathering in which this species was observed was collected on the 13th of July to the east of Hope Island at a depth of 100 to 110 fathoms; the species appeared to be very rare. 


\section{Dactylopus tisboides, Claus.}

This common and generally distributed species occurred in a sample collected on the west side of Bear Island on July 3rd, but, as in the case of most of the others, only a few specimens were observed.

\section{Dactylopus longirostris, Claus.}

Dactylopus longirostris was obtained in the same gathering with $D$. tenuiremis, collected to the east of Hope Island on July 13 th.

\section{Dactylopus flavus, Claus.}

The gathering in which D. Alavus occurred was collected in 60 fathoms in lat. $76^{\circ} 17^{\prime} \mathrm{N}$., long. $21^{\circ} 36^{\prime} \mathrm{E}$., on July 20th.

Dactylopus Brucei, T. \& A. Scott (sp. n.). (Pl. IV. figs. 1-6.)

One or two specimens of this Dactylopus were obtained in a sample of bottom-material from 20 fathoms somewhere off Kostyn Point, Novaya Zemlya, or between there and Kolguev Island, collected on June 16th, 1898. As the species appears to be "new," we submit the following description of the female (no male was observed) :-

Body moderately slender; rostrum short but distinct; caudal furca very short, each furcal joint is furnished with a stout and moderately long, lance-shaped, terminal spine, in addition to a few minute hairs (fig. 1) ; the length of the specimen figured is about $\cdot 77 \mathrm{~mm}$. ( $\frac{1}{32}$ of an inch).

The antennules are short and eight-jointed; the first four joints are moderately large and subequal, but the last four are smaller (fig. 2); the proportional lengths of the different joints are shown approximately by the formula :-

$\begin{array}{lllllllll}\text { Number of the joints ...... } & 1 & 2 & 3 & 4 & 5 & 6 & 7 & 8\end{array}$

Lengths of the joints..... $11 \cdot 10 \cdot 12,12,5 \cdot 6 \cdot 5 \cdot 7^{\circ}$

The antennæ and most of the mouth-appendages are somewhat similar to the same appendages in Dactylopus Strömii (Baird), but the second maxillipeds are rather more slender and armed with long terminal claws (fig. 3).

The first pair of swimming-feet are moderately stout (fig.4); the proximal joint of the inner branches is robust and equal to rather more than one and a half times the entire length of the other two, which are small and subequal; a moderately long plumose seta springs from near the end of the inner margin of the first joint, while the third joint is armed at the 
apex with a slightly clawed spine of moderate length and an elongated seta; the outer branches are scarcely equal in length to the inner ones; a stout spine springs from the outer distal angles of the first and second joints, while the third carries two similar spines and two elongated setæ at its distal end. The second, third, and fourth pairs are somewhat similar to those of Dactylopus Strömii, but are rather more slender; figure 5 represents the fourth pair. The fifth pair in the present species has also a resemblance to the same pair in Dactylopus Strömii, but slight differences are observable, especially in the shape of the secondary joints, which are oval in form and about twice as long as broad (fig. 6); in these joints an elongate slender seta springs from near the middle of the interior margin and another from near its distal end, in addition to three long apical setæ; the produced part of the basal joint is also furnished with five setæ, which are arranged round the distal half of the outer margin and apex, as shown in the figure.

The stout lance-shaped spine, with which each of the caudal furca is armed, forms a character by which the species can be readily identified. The species is named in compliment to Mr. Bruce, who has done so much in the interests of Arctic and Antarctic research.

\section{Thalestris forficulus, Claus.}

This species was observed very sparingly in samples of bottom-material from 20 fathoms collected between Kolguev and Novaya Zemlya on June 11th; from the west side of Bear Island, collected on July 3rd; and from 27 fathoms off Hope Island, collected on the 6th of the same month.

\section{Thalestris Krohnii (Kröyer).}

Syn. Thalestris serrulatus, Brady, Monograph Brit. Copepoda, vol. ii. p. 133, pl. lix. figs. 2-11.

This fine species, which sometimes makes its appearance in the British seas, was captured by tow-net between South Cape, Spitzbergen, and Bear Island on July 22nd, and in Kval Sound on the 24 th of the same month; both males and females were obtained.

\section{Thalestris helgolandica, Claus.}

This species occurred in a gathering from Kval Sound collected on July $24 \mathrm{th}$, but only a single specimen was observed. 


\section{Harpacticus chelifer (Müller).}

One or two specimens of this Copepod were noticed in a tow-net gathering collected in Kval Sound on July 24th; while several of the variety arcticus, Poppe $*$, were obtained amongst bottom-material chiefly collected on the west side of Bear Island on July 3rd, near Hope Island on July 7th, and in lat. $76^{\circ} 33^{\prime} \mathrm{N}$., long. $33^{\circ} 43^{\prime} \mathrm{E}$., on July 13 th.

\section{Zaus spinatus, Goodsir.}

Specimens of Zaus spinatus were not uncommon in one or two bottom-gatherings collected near Kolguev Island and between there and Novaya Zemlya in June.

\section{Zaus Goodsiri, Brady.}

A specimen of this fine species, measuring $1.4 \mathrm{~mm}$. $\left(\frac{1}{18}\right.$ of an inch), was obtained in a sample of bottom-material trom 100 fathoms collected in lat. $76^{\circ} 24^{\prime} \mathrm{N}$., long. $33^{\circ} 43^{\prime} \mathrm{E}$., on July 13 th.

\section{Zaus Aurelii, Poppe. (Pl. IV. figs. 7-12.)}

1884. Zaus Aurelii, Poppe, Ueber die von den Herren Dr. Arthur u. Aurel Krause im nördl. Stillen Ocean u. Behrings-Meer gesammelten freilebenden Copepoden (Arch. f. Naturgesch. 50 Jahrg. i. Bd.), p. 286, Taf. xx. figs. 7-9, Taf. xxi. figs. 5-15.

Specimens of a Copepod which appear to us to belong to Poppe's Zaus Aurelii were obtained in a bottom-gathering from 20 fathoms between Kolguev Island and Novaya Zemlya collected on June 16th. In the adult female, of which we give a drawing (see Pl. IV. fig. 7) the cephalic and thoracic segments are scarcely so broad as they are shown to be in Dr. S. A. Poppe's figure, but a slight amount of extra pressure on the cover-glass under which the specimen was placed might be sufficient to account for this. The Kolguev specimens appear also to be rather smaller than those from the North Pacific and Behring's Sea; but, as will be seen by

* Mr. T. Scott, in his "Report on Franz-Josef Land Crustacea " (Journ. Linn. Soc., Zool. vol. xxvii.), describes and figures a variety of $H$. chelifer under the name of var, arcticus. At this time he was unaware of the fact that Dr. S. A. Poppe had in 1834 published a paper on some North Pacitic and Behring's Sea Copepods. In this paper Ir. Poppe has also described a var. arcticus of the same species, and it is interesting to note that the variety described by $\mathrm{T}$. Scott is practically identical with that described by Dr. Poppe. Dr. Poppe's varietal name hus, of course, clear priority over Mr. Scott's, and must therefore be adopted. 
comparing our figures with those of $\mathrm{Dr}$. Poppe, the structural details are practically the same.

\section{Idya furcata (Baird).}

This species was observed in a shore-gathering from the east side of Kolguev Island, collected on June 12 th.

Fam. Lichomolgidæ.

\section{Lichomolgus hirsutipes, T. Scott.}

1893. Lichomolgus hirsutipes, T. Scott, Eleventh Ann. Rept. Fishery

Board for Scotland, pt. iii. p. 206, pl. iv. figs. 1-12.

This, like the Idya furcata recorded above, was obtained in the shore-gathering from the east side of Kolguev Island, but was apparently very rare.

\section{Fam. Asterocheridæ.}

\section{Asterocheres simulans (T. Scott).}

1898. ? Ascomyzon simulans, T. Scott, Sixteenth Ann. Rept. Fishery Board for Scotland, pt. iii. p. 270, pl. xiii. figs. 1-9, pl. xiv. fig. 22.

One or two specimens of this Asterocheres were found in a sample of bottom-material from 100 fathoms collected east of Hope Island on July 13 th.

\section{Asterocheres Boecki (Brady).}

A few specimens of $A$. Boecki (Brady) occurred in a gathering collected in the vicinity of Hope Island in 27 fathoms on July 6 th.

\section{Dermatomyzon nigripes (Brady \& Robertson).}

This fine species was taken in 60 fathoms, along with icolef Cletodes abyss and others, in lat. $76^{\circ} 17^{\prime} \mathrm{N}$, long. $21^{\circ}$ $36^{\prime}$ E., on July 20 th.

\section{Parartotrogus Richardi, T. \& A. Scott, var. arctica, var. nov. (Pl. VI.)}

1893. Parartotrogus Richardi, T. \& A. Scott, Ann. \& Mag. Nat. Hist. (6) vol. xi.p. 210, pl. vii. figs. 1-11.

One or two specimens apparently belonging to this species were found in the same gathering with Asterocheres simulans from 100 fathoms to the east of Hope Island, and in another 
collected off Kolguev in June. As one or two slight differences have been observed between these specimens and those obtained in the Firth of Forth, we submit the following remarks on these differences as well as on the otherwise close similarity of the Arctic and Scottish specimens.

Figure 1 (Plate VI.) is a drawing of one of the Arctic female specimens; this specimen measures $78 \mathrm{~mm}$. ( ${ }_{30}^{1}$ of an inch), and is thus proportionally larger than those from the Firth of Forth.

The antennules and antennæ (figs. $2 \& 3$ ), the multhappendages (figs. 4 to 7 ), and the first, second, and fitth pairs of thoracic feet (figs. $8,9, \& 12$ ) are similar to the same appendages in the Scottish specimens. The third pair of thoracic feet have the inner branches three-jointed and armed with an elongated dagger-like terminal spine in addition to several plumose seta; but in the specimens from the Firth of Forth the inner branches of the same pair are only two-jointed, they are not provided with terminal spines but carry instead two slender apical seta; it may be observed, however, that though the imner branches of the Forth specimens are only two-jointed, the end joint is long and maly therefore consist of two coalesced joints, which, under the influence of the altered conditions to which the Arctic specimens may be exposed, have become distinct; these altered conditions may also explain the difference in the armature of the branches.

But in addition to this difference in the third pair of thoracic feet between the Arctic and Scottish specimens, there is the presence, in the Arctic specimens, of what appears to be a very small and rudimentary tourth pair of thoracic feet, each consisting of a small lamelliform basal joint, and a minute secondary one bearing two dagger-like apical spines (fig. 11). In the specimens trom the Firth of Forth, on the other hand, the presence of a fourth pair has not been observed*. This rudimentary fourth pair in these Aretic specimens is, perhaps, a more important difference than the other; but as the Arctic and Scottish specimens appear to agree so closely in every other respect, we can meantime regard this northern form only as a variety of Parartotrogus Richardi.

* In the oricinal description of I'arartotroyus Richurdi in the Ann. it Mag. Nat. Hist. (6) vol. xi. 1). 210 , the authors were somewhat uncertain whether it was the second or the fourth pair that was wanting ; but Dr. Giesbrecht of Naples has shown that it is the fourth pair, so that the "? third and fourth pairs" in the origrinal description should be the "second and third pairs." 
The male is very like the female but is rather smaller; the antennules (fig. 14) appear to consist of eleven instead of nine joints, and the end joints are linged and adapted for grasping; the abdomen (fig. 15) is composed of five instead of four segments, but otherwise there is little apparent difference between the two sexes.

\section{Os T R A C O D A.}

The following O-tracoda have been observed in some of the gatherings:-

Candona Harmsworthi, '1'. Scott.-A number of adult and apparently immature specimens of this Candona occurred in one or two gatherings from ponds of slightly brackish water at the south end of Novaya Zimlya - the first near Kostyn Point on June 18th, and the other near Cape Chetney on June 21st. 'This is one of the species described by T. Scott in his "Report on Frinz-Joset" Land Crustacea" *.

Cythere concinna, Jones.-A few specimens in a gathering from 60 fathoms, collected July 20 in lat. $76^{\circ} 17^{\prime} \mathrm{N}$., long. $21^{\circ} 36^{\prime} \mathrm{E}$.

Cythere costata, G. S. Brady.-In the same gathering with the last; rare. In this gathering the tollowing additional species were also observed:-

Cythere emarginatu (G. O. Sars).-Rare.

('ythere globulifera, G. S. Brady.-Rare.

Cythere tuberculata (G. O. Sars).-Rare.

('ythere dunelmensis (Norman).-Rare.

Limnicythere inopinata (Baird).

A single specimen of Limnicythere inopinata occurred in the gathering from Cape Chetney, Novaya Zemlya ; it somewhat resembles the form described by Dr. Dihl as Limnicythere incisu $\dagger$, but the shell is rather more compressed at the posterior end.

* Journ. Linn. Soc., Zool. vol. xxvii. (no. 174) p. 8s, pl, iii. figgs. 16, 17 (1899).

† "Die Cytheriden der westlichen Ostsee," Zool. Jahrb. Bd. iii. (1888) p. 20, pl. ii. tigs. 49-58. 
Cytheridea papillosa, Bosquet. -60 fathoms, lat. $76^{\circ} 17^{\prime} \mathrm{N}$., long. $21^{\circ} 36^{\prime}$ E., collected July 20 th ; rare.

Cytheridea punctillata, G. S. Brady.-In the same gathering with the last; rare.

Xestoleberis depressu, G. O. Sars.-Collected in the vicinity of Hope Island in 27 fathoms, July 6th, 1895; rare.

The next three species are from the same gathering.

Xestoleberis aurantia (Bair I).-Rare.

Sclerochilus contortus (Norman).-Rare.

Paradoxostoma variabile (Bıird).-Rare.

Philomedes brenda (Baird).-This species was captured in the surface tow-net to the north of Bear lstand ou July 5th; it also occurred in other two gratherings collected on the 12th and 13 th of the same month.

\section{CLA D O C E R A.}

A few ephippia, apparently of sume species of Daphnia, were the only representatives of the Cladocera observed in this collection; they occurred in the gatherings from the ponds at Kostyn Point and Cape Chetney, Nuvaya Kemlya.

\section{EXPLANATION OF THE PLATES.}

Plate III.

Jonesiella Brucei, sp. n.

Fig 1. Female, seen from left side, $\times 80$. 2. One of the antennules, $\times$ 190. 3. One of the antennre, $\times 190$. 4. Mandible and palp, $\times 190$. 5. Maxilla, $\times 250$. 6. Second maxilliped, $\times 250$. 7. Foot of tirst pair, $\times 127.8$. Foot of fourth pair, $\times$ 127. 9. Fitth foot, $\times 250$. 10. Last abdominal segment and caudal furca, $\times 126$.

\section{I'LATE IV.}

Dactylopus Brucei, sp. n.

Fiy. 1. Female, see from the left side, $\times 106.2$. One of the antennules, $x$ :iso, 3. One of the second maxillipeds, $\times 250$. 4. Foot of fir'st pair, $\times 250$. 5. Foot of fourth pair, $\times 250$. 6. Fifth toot, $\times 250$.

Zaus Aurelii, Poppe.

Fiy. 7. Female, dorsal view, $\times 80.8$. One of the antennules, $x$ 254. 9. One of the second maxillipeds, $\times 254$. 10. Foot of tirst pair, $\times 190$. 11. Fifth foot, $\times 170$. 12. Abdomen and caudal furea, $\times 95$. 


\section{Plate V.}

Cletodes abyssicola, sp. n.

Fig. 1. Female, dorsal view ( $a$ and $b$, dorsal spines seen in profile), $\times 100$. 2. One of the antennules, $\times 250$. 3. One of the antennæ, $\times$ 500. 4. Mandible and palp, $\times$ 760. 5. Second maxilliped, $\times 760$. 6. Foot of first pair, $\times 500$. 7. Foot of fourth pair, $\times 340$. 8. Fifth foot, $\times 250$.

Cletodes Brucei, sp. n.

Fig. 9. Female, dorsal view, $\times 106$. 10. Foot of fourth pair, $\times 250$. 11. Fifth foot, $\times 380$.

\section{Plate VI}

Parartotrogus Richardi, T. \& A. Scott, var. arctica.

Fig. 1. Female, dorsal view, $\times 80$. 2. One of the antenuules, $\times 190$. 3. One of the antennix, $\times 190$. 4. Mandible, $\times 380$. 5. Maxilla, $\times 253$. 6. First maxilliped, $\times 127$. 7. Second maxilliped, $\times 127$. 8. Foot of first pair, $\times 170$. 9. Foot of second pair, $\times 123$. 10. Foot of third pair, $\times 123$. A1. Foot of fourth pair, $\times 500$. 12. Fifth foot, $\times 380$. 13. Abdomen and caudal furca, $\times 84$. 14. One of the antennules, male, $\times 190$. 15. Abdomen and caudal furca, male, $\times 84$. 
Anu \& Mag. Nat. Hist. S. 7. Vol. VIII.PU. III.

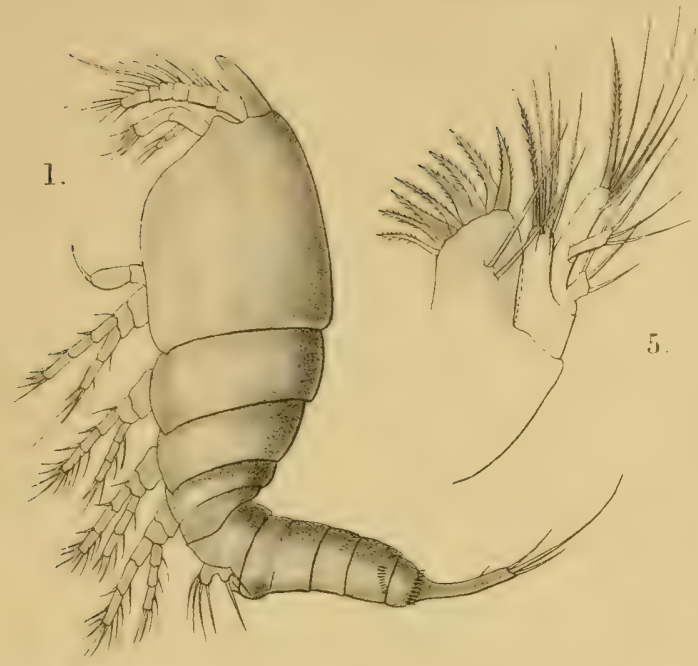

新

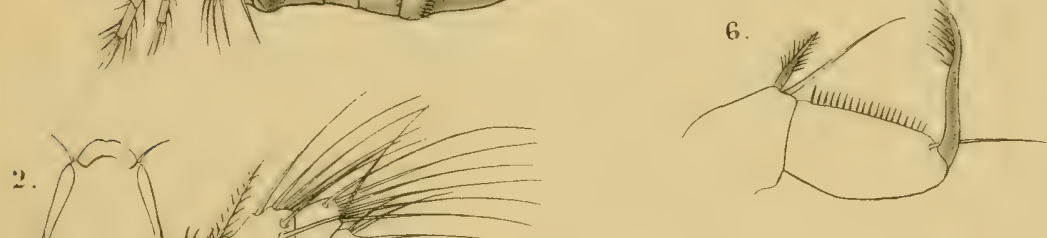

7.
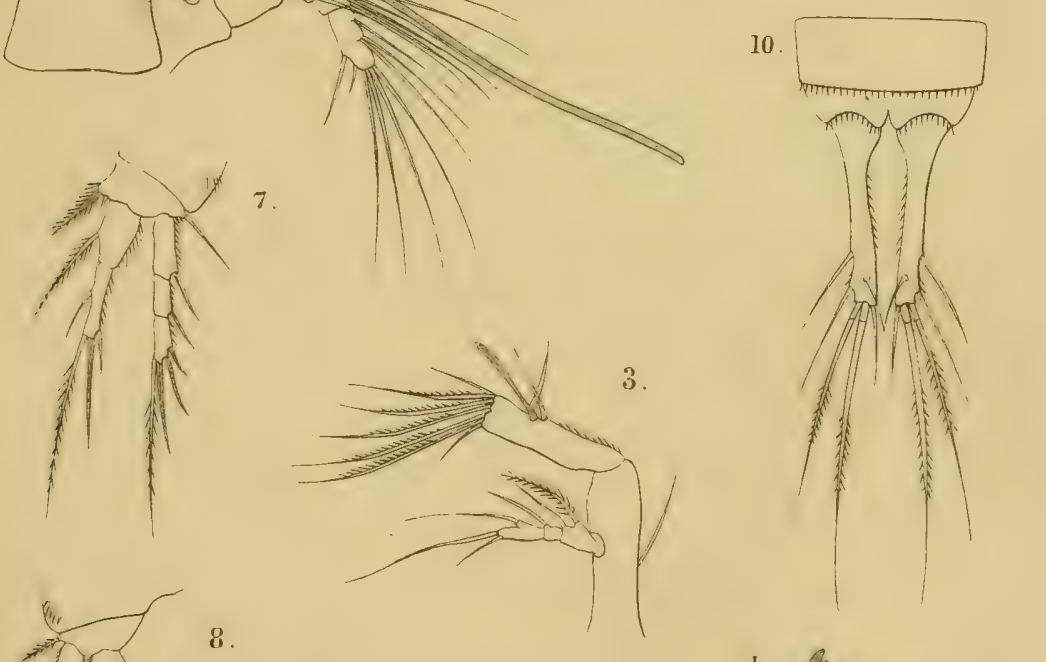

8
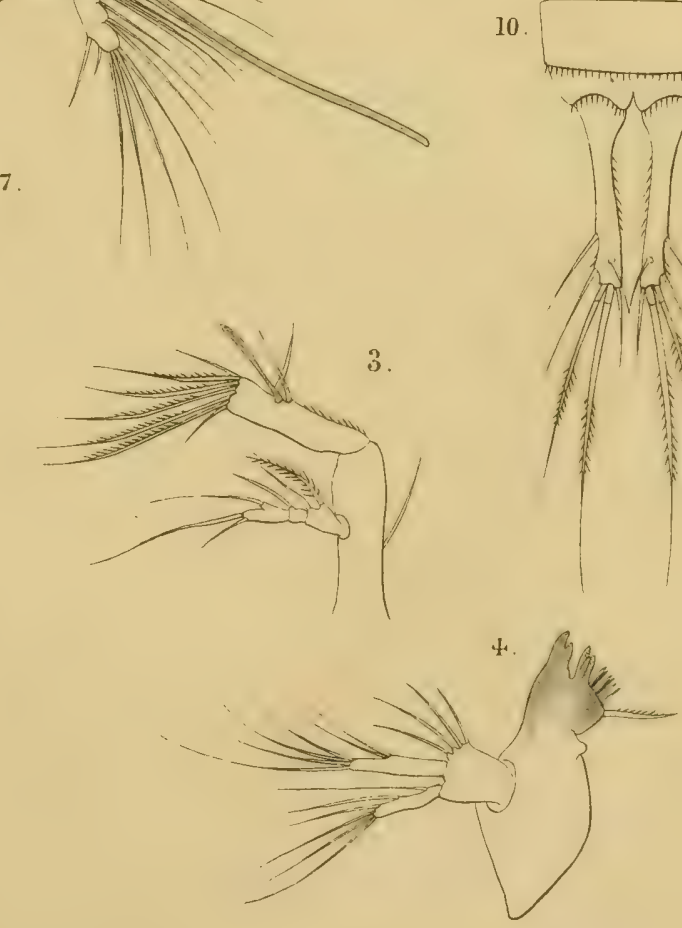

A. Scott del.

R. E. Mintern Jith.

Mintern Bros.imp. 

Ann \& Mag. Nat. Hist. S. 7. Vol. VIII. PI. IV.
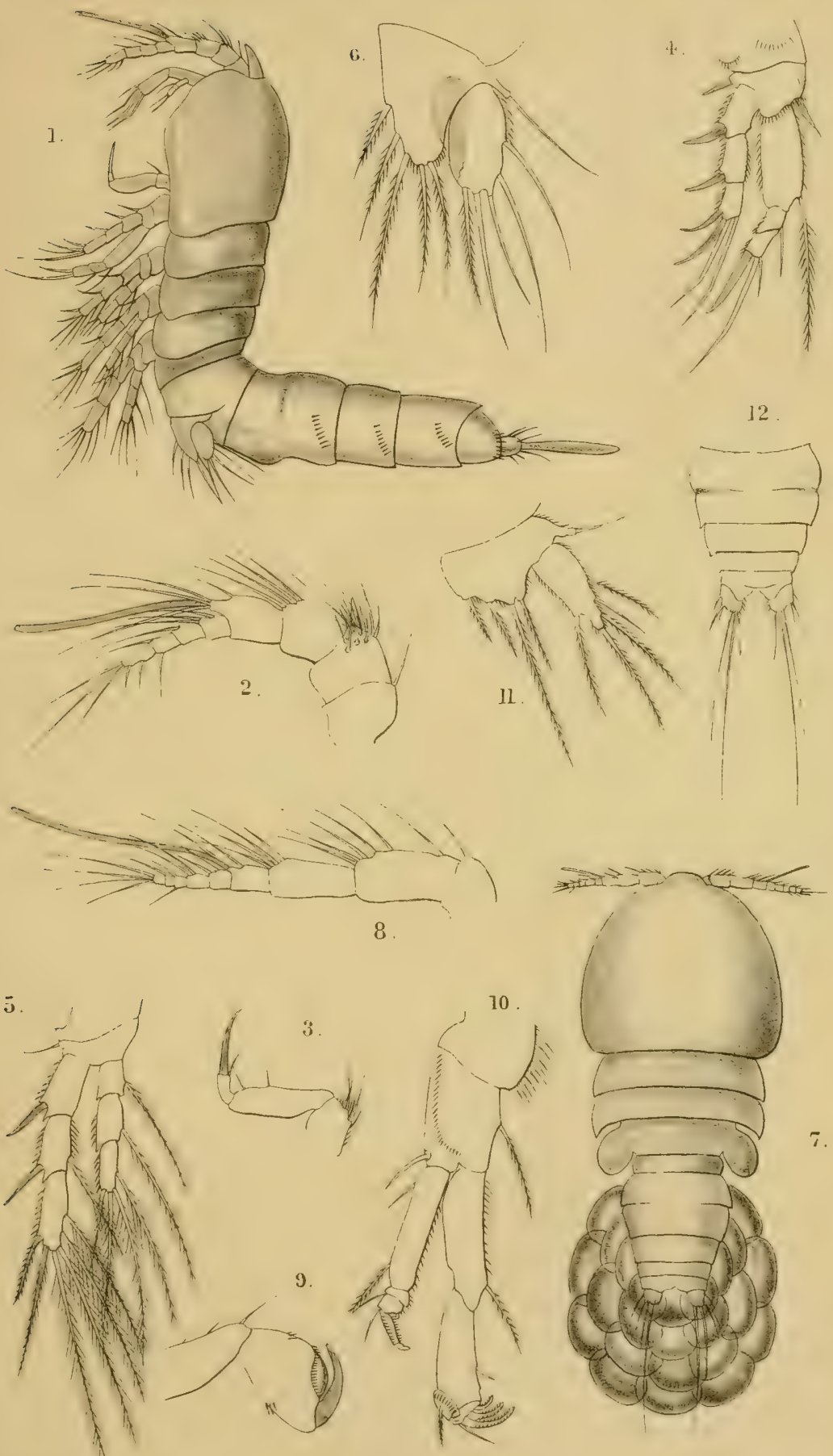

A. Scott del

Mintern Zros.imp.

7-12, ZAUS AURELII, Poppe. 

Ann.\& Mag. Nat. Hist. S.7.Vol.VIII.PL.V.
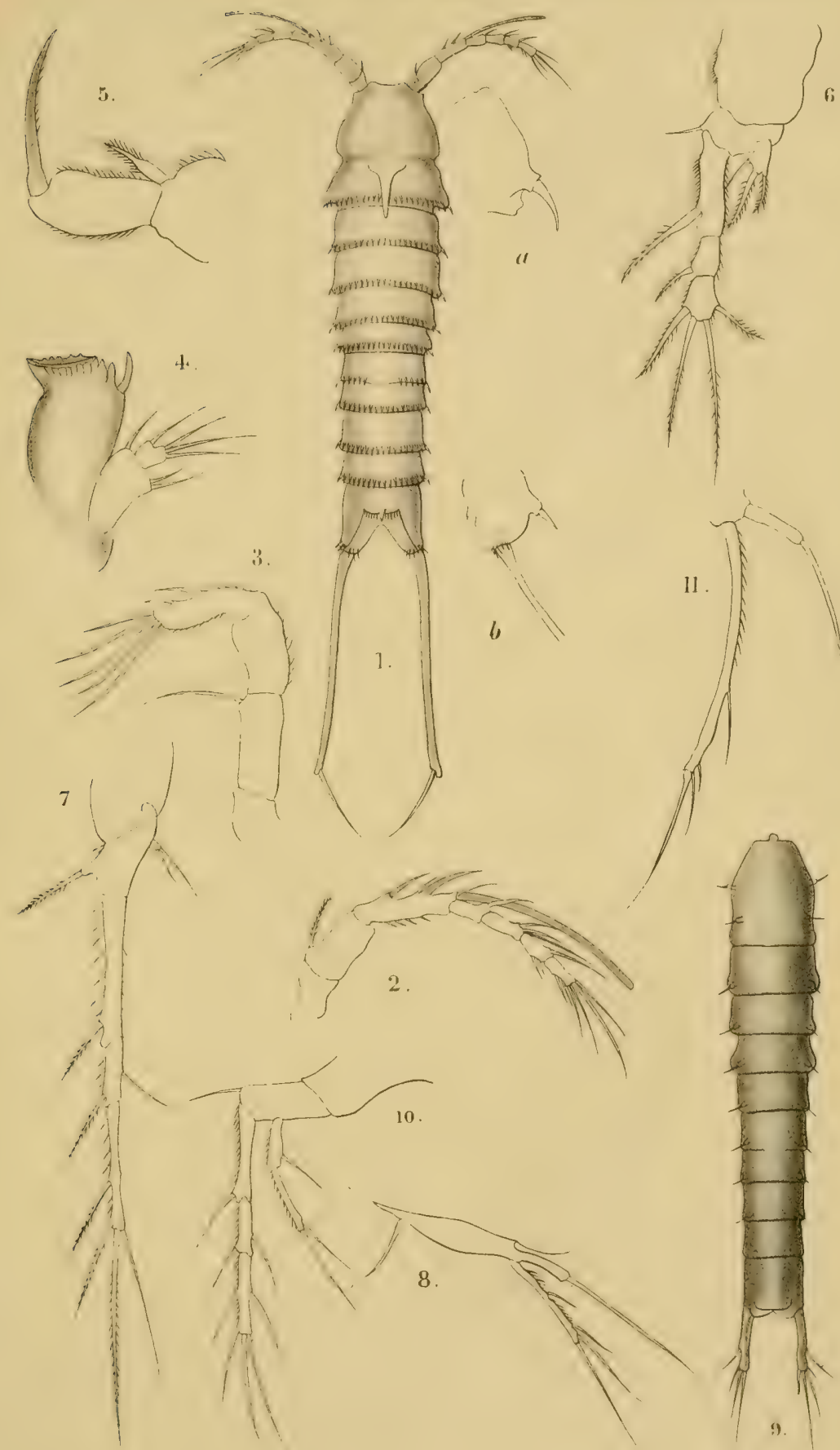

10.

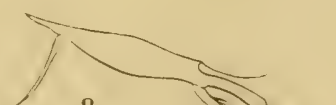

8.

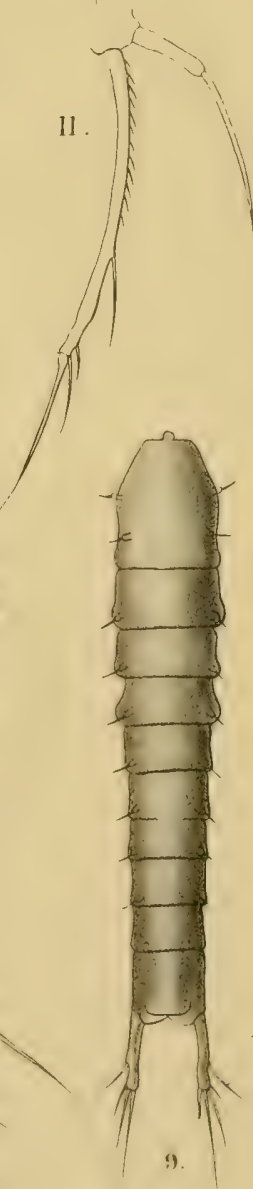

R.E.Mintern lith.

Mintern Bros.imp

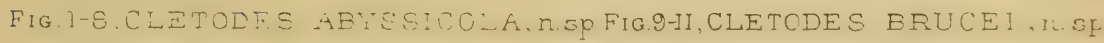



Ann \& Mag. Nat. Hist. S. 7.VoZ.VIII PL VI.
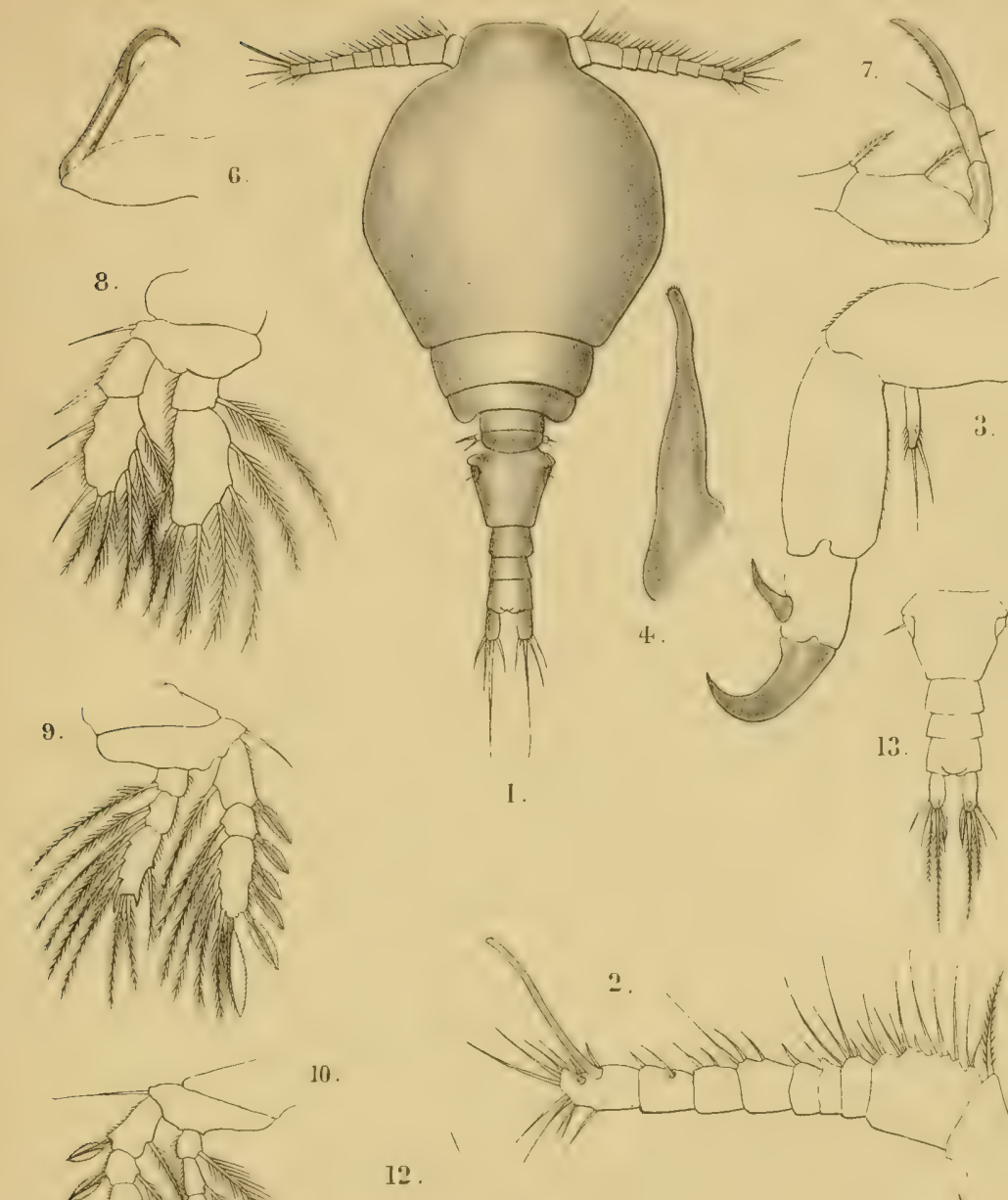

10.

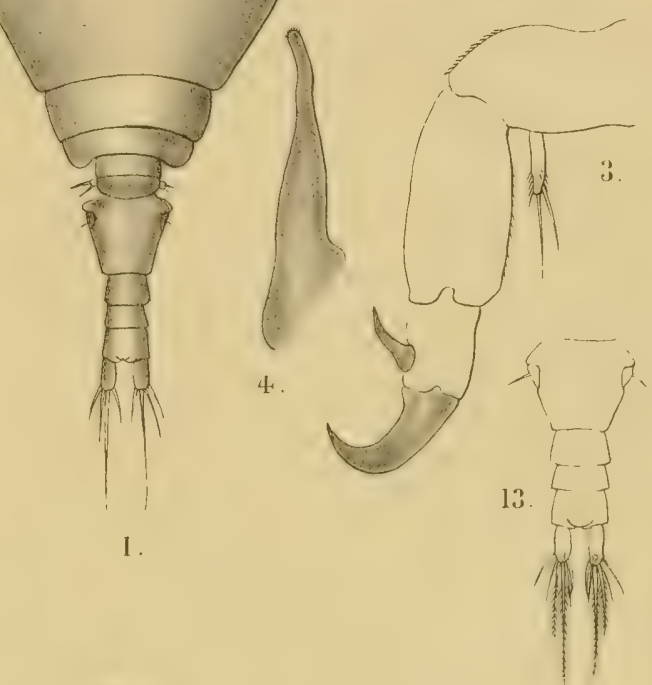

12.
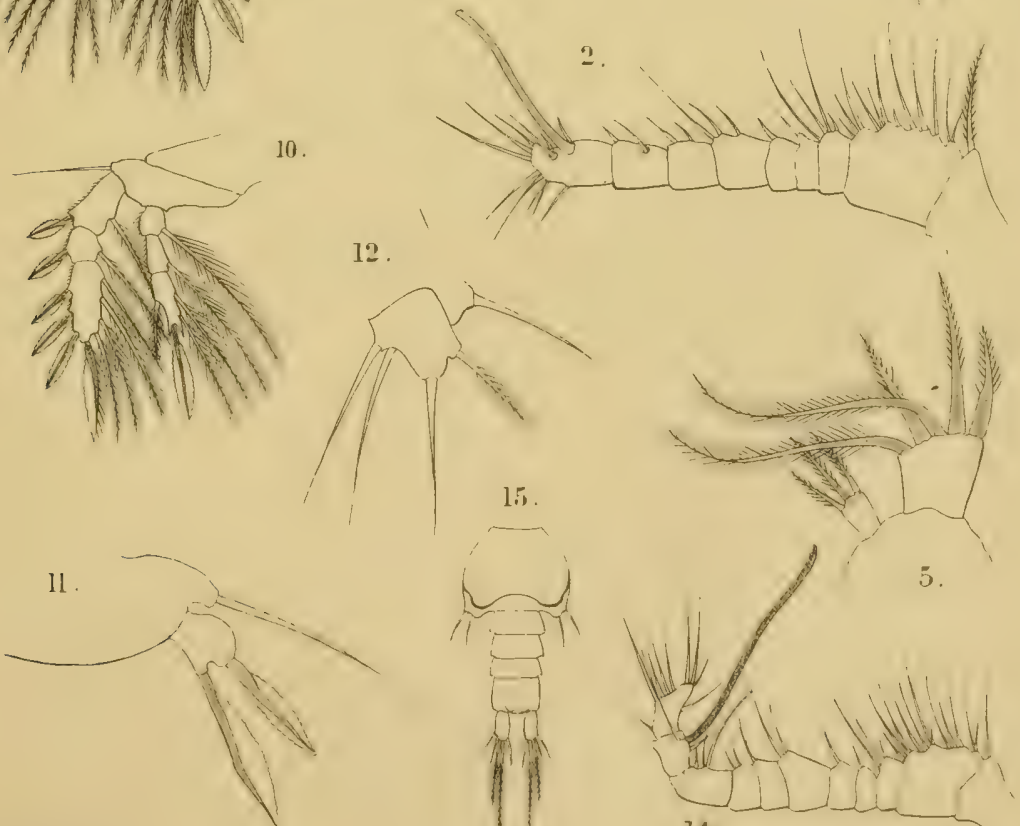

R. E. Mintern lith

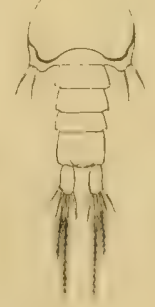

5.

PARARTOTROGUS RICHARDI, T. \& A.Scott, var. ARCTICA.nov.var. 


$933 \div 333-50$

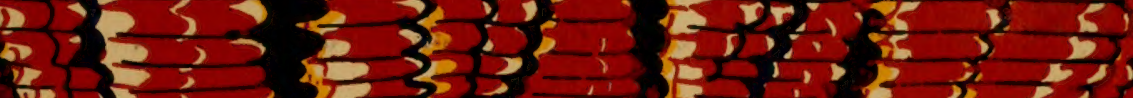

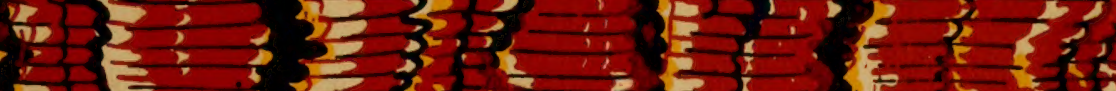

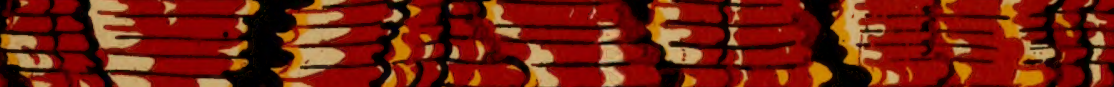

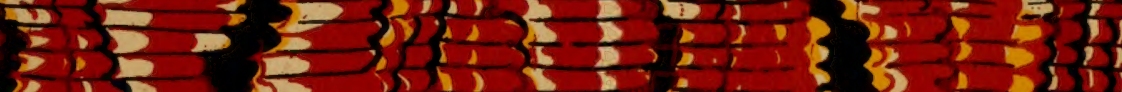

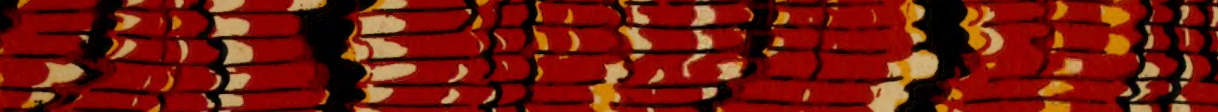

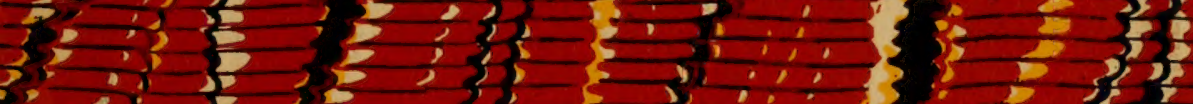

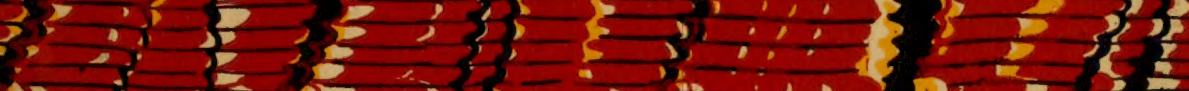

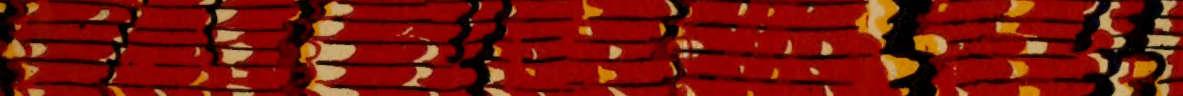

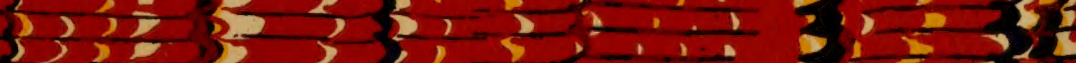

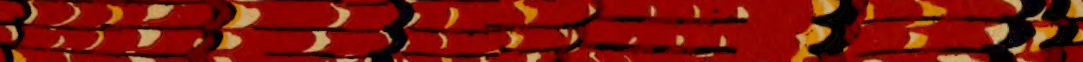

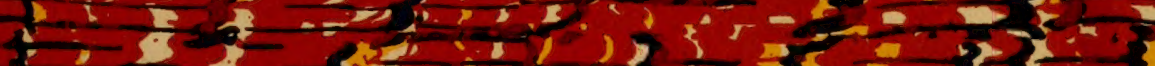

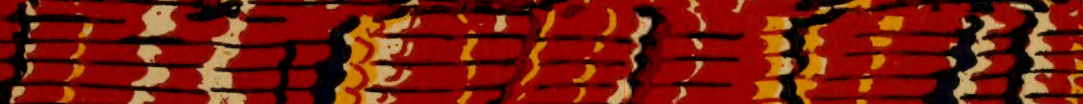

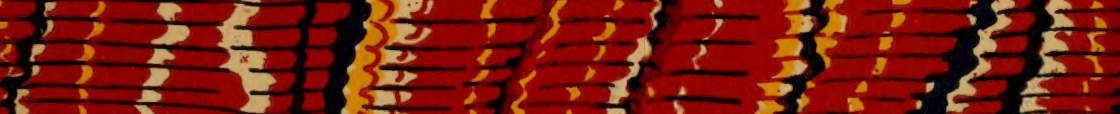

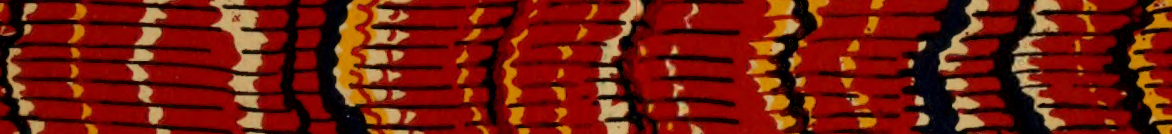

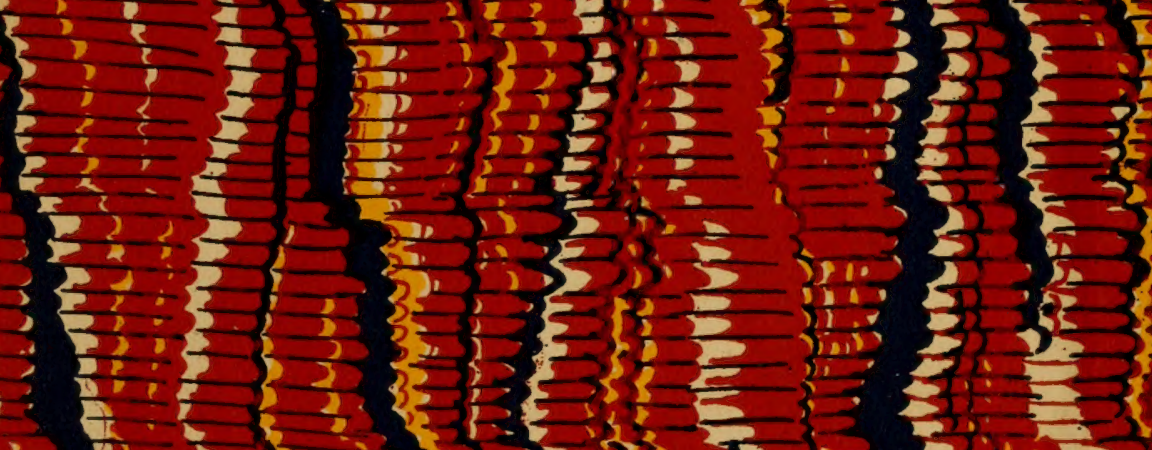

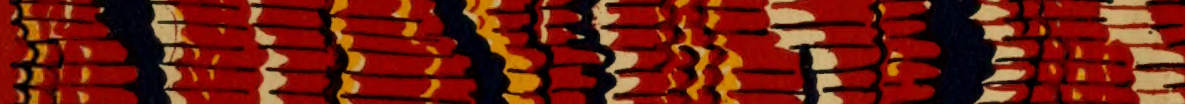

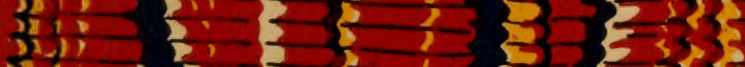

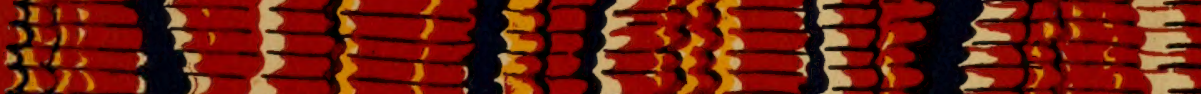

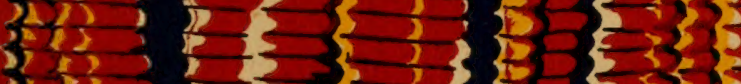

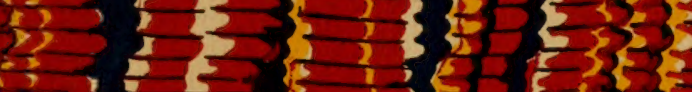

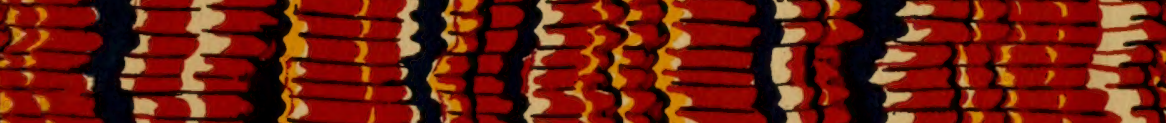

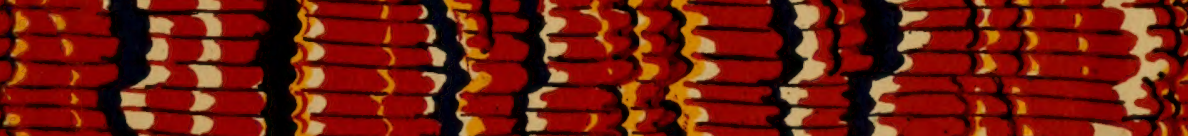

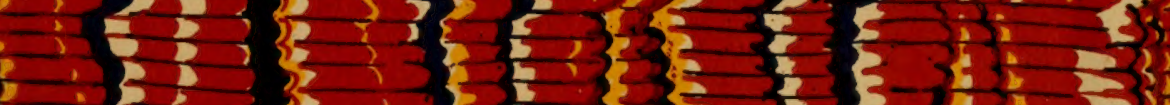

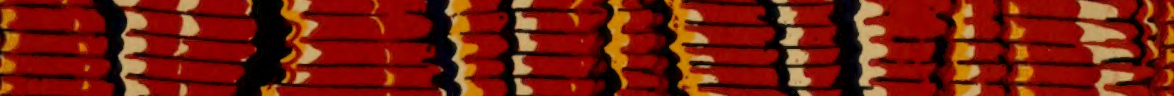

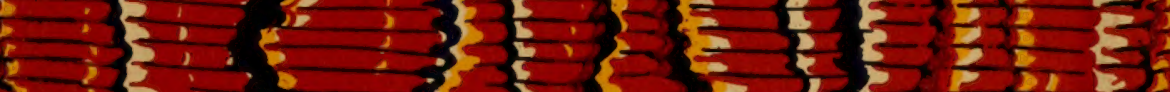

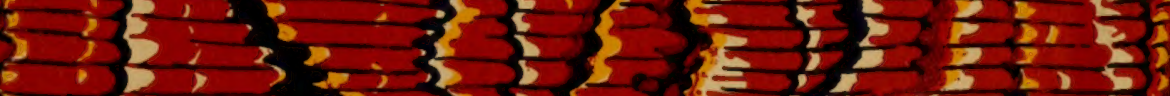

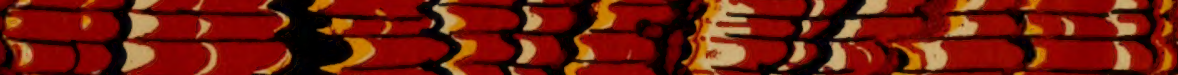

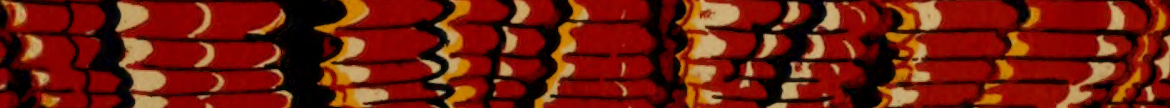

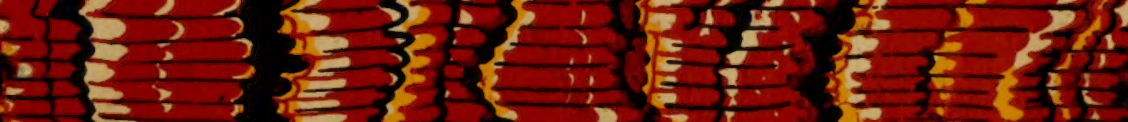
$x-3 x$ 


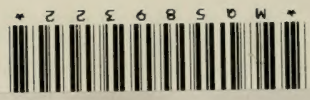

